\title{
Cell cycle analysis of primary sponge cell cultures
}

\author{
Klaske J. Schippers • Dirk E. Martens • \\ Shirley A. Pomponi • René H. Wijffels
}

Received: 27 October 2010 / Accepted: 26 January 2011 /Published online: 17 March 2011 / Editor: J. Denry Sato

(C) The Author(s) 2011. This article is published with open access at Springerlink.com

\begin{abstract}
Proliferation of sponge cells is generally measured via cell counts or viability assays. However, more insight into the proliferative state of a sponge cell population can be obtained from the distribution of the cells over the different phases of the cell cycle. Cell cycle distribution of sponge cells was measured via flow cytometry after staining the DNA with propidium iodide. The five sponges studied in this paper all showed a large fraction of cells in G1/G0 compared to G2/M and S, indicating that cells were not actively dividing. In addition, some sponges also showed a large apoptotic fraction, indicating cell death. Additional apoptosis measurements, based on caspase activity, showed that harvesting and dissociation of sponge tissue to initiate a primary cell culture was directly correlated with an increase in apoptotic cells. This indicates that for the development of cell cultures, more attention should be given to harvesting, dissociation, and quality of starting material. Finally, cultivation conditions used were ineffective for proliferation, since after $2 \mathrm{~d}$ of cultivating Haliclona oculata cells, most cells shifted towards the apoptotic fraction, indicating that cells were dying. For development of in vitro sponge cell cultures, flow cytometric cell cycle analysis is a useful method to assess the proliferative state of a sponge cell culture and can be used to validate improvements in
\end{abstract}

K. J. Schippers $(\bowtie) \cdot$ D. E. Martens $\cdot$ R. H. Wijffels Bioprocess Engineering, Wageningen University,

P.O. Box 8129, 6700 EV Wageningen, The Netherlands

e-mail: klaske.schippers@wur.nl

\section{S. A. Pomponi}

Harbor Branch Oceanographic Institute,

Florida Atlantic University,

5600 U.S. 1 North,

Fort Pierce, FL 34946, USA harvesting and dissociation, to select sponges with good proliferative capacities and to study the influence of culture conditions for stimulating cell growth.

Keywords Sponge cell culture $\cdot$ Cell cycle analysis $\cdot$ Flow cytometry $\cdot$ Apoptosis $\cdot$ Caspase

\section{Introduction}

Marine sponges are a rich source of bioactive compounds, which have the potential to provide future medicines, such as new antibiotics, anticancer drugs, and antiviral compounds (Munro et al. 1999; Sipkema et al. 2005a). However, the limited availability of sponge biomass hampers the development of these potential drugs into commercial products (Pomponi 1999; Sipkema et al. 2005b). An approach to increase sponge biomass availability can be in vitro sponge cell culture (Pomponi 2006; De Caralt et al. 2008; Koopmans et al. 2009). Despite efforts by different research groups, a continuous sponge cell line has not yet been developed and the number of primary sponge cell cultures developed is very limited (Rinkevich 2005). Apart from inappropriate culture conditions for growth, one possible explanation is that the sponge cells are already in a non-proliferative state at the start of the culture, either because they were taken from a sponge in a resting non-proliferative state or as a consequence of the dissociation process.

Proliferation of sponge cells is usually measured by cell counts and viability assays (e.g., trypan blue, FDA, and PI (Sipkema et al. 2004)). However, counting cells is time consuming and inaccurate due to the large variety of cell sizes in a sponge, which makes it difficult to discriminate between sponge cells and certain contaminants, like yeast 
and protozoa. In addition, cell counts may not always correctly represent what is happening, because they do not give information about the status of the cells, but only discriminate between viable and dead cells. For example, cells in early apoptosis do not have a leaky membrane and will therefore not be detected by trypan blue or the FDA/PI method.

Information on the proliferative state of a cell population can be obtained from the distribution of the cells over the different phases of the cell cycle. Cell populations which are actively dividing have a large fraction of cells in the $\mathrm{S}$ phase, while cell populations that are not actively dividing have a large fraction in the G1/G0 phase (most mammalian cell lines) or in the G2/M phase (insect cells) (Fertig et al. 1990). The cell cycle distribution can be measured with flow cytometry after staining the DNA in the cells with propidium iodide. Also apoptotic populations can be detected, since apoptotic cells fragment their DNA, which results in a sub-G1 peak (Pozarowski and Darzynkiewicz 2004). Apoptosis can also be detected by measuring caspase activity. Caspases are a family of cysteine proteases and play an essential role in apoptosis and can therefore be used as indicators for apoptosis (Nicholson and Thornberry 1997; Wiens and Muller 2006). An important advantage of these methods is that they give information about the condition of the cells already at the start of the culture while for cell counting it takes a few days to see whether there is cell growth or death.

The aim of this research was to evaluate the potential of flow cytometric cell cycle analysis to measure the proliferative state of sponge cells.

The cell cycle distribution of five different species obtained from different locations was analyzed: Haliclona oculata and Haliclona xena from Lake Grevelingen in The Netherlands, Dysidea avara and Axinella polypoides from the Mediterranean at the Costa Brava in Spain, and Xestospongia muta from Dania Beach in Florida, USA. Next to this we also measured the cell cycle distribution and caspase activities of cells from $H$. oculata during a 2- and 10-d cultivation to study the change in distribution of cells over time.

\section{Material and Methods}

Specimen collection and transportation. Specimens of the sponges (see Table 1.) were collected by scuba diving. $H$. oculata and $H$. xena were collected from Lake Grevelingen (Dreischor:Frans Kokreef) in The Netherlands ata depth of approximately $8 \mathrm{~m}$. Specimens of $D$. avara and A. polypoides were collected from the Mediterranean (Cala Montgo) in Spain at a depth of approximately 8-10 m. $X$. muta was collected from Florida (Dania Beach) in the USA at a depth of approximately $10 \mathrm{~m}$. The sponges were transported in coolers to maintain the temperature the same
Table 1. Sponge collection

\begin{tabular}{|c|c|c|c|}
\hline Sponge & $\begin{array}{l}\text { Location of } \\
\text { harvest }\end{array}$ & Date of harvest & Storage \\
\hline $\begin{array}{c}\text { Haliclona } \\
\text { oculata }\end{array}$ & $\begin{array}{l}\text { Lake } \\
\text { Grevelingen, } \\
\text { Dreischor: } \\
\text { Frans Kok } \\
\text { reef }\end{array}$ & $\begin{array}{l}16-11-2009 \text { and } \\
11-1-2010\end{array}$ & $\begin{array}{l}70 \% \mathrm{EtOH} \\
-20^{\circ} \mathrm{C}\end{array}$ \\
\hline $\begin{array}{l}\text { Haliclona } \\
\text { xena }\end{array}$ & $\begin{array}{l}\text { Lake } \\
\text { Grevelingen, } \\
\text { Dreischor: } \\
\text { Frans Kok } \\
\text { reef }\end{array}$ & 16-11-2009 & $\begin{array}{l}70 \% \mathrm{EtOH} \\
-20^{\circ} \mathrm{C}\end{array}$ \\
\hline $\begin{array}{c}\text { Dysidea } \\
\text { avara }\end{array}$ & $\begin{array}{l}\text { Mediterranean, } \\
\text { Cala Montgo, } \\
\text { l'Escala }\end{array}$ & $22-1-2008$ & Cryopreserved \\
\hline $\begin{array}{l}\text { Axinella } \\
\text { polypoides }\end{array}$ & $\begin{array}{l}\text { Mediterranean, } \\
\text { Cala Montgo, } \\
\text { l'Escala }\end{array}$ & $17-6-2009$ & $\begin{array}{l}70 \% \mathrm{EtOH}, \\
-20^{\circ} \mathrm{C}\end{array}$ \\
\hline $\begin{array}{l}\text { Xestospongia } \\
\text { muta }\end{array}$ & $\begin{array}{l}\text { Dania Beach, } \\
\text { Florida }\end{array}$ & $18-9-2007$ & Cryopreserved \\
\hline
\end{tabular}

as in the sea and were constantly aerated. Cells from $D$. avara and X. muta were cryopreserved, stored, and thawed based on the method of Pomponi et al. (1997).

Media and solutions. Calcium- and magnesium-free seawater, CMF-EDTA $(10 \mathrm{mM})$, was prepared by dissolving $32.1 \mathrm{~g} \mathrm{NaCl}, 1.1 \mathrm{~g} \mathrm{Na}_{2} \mathrm{SO}_{4}, 0.9 \mathrm{~g} \mathrm{KCl}, 10 \mathrm{ml}$ of Trizma $(0.5 \mathrm{M}, \mathrm{pH} 8.0)$, and $20 \mathrm{ml}$ of $0.5 \mathrm{M}$ EDTA stock solution in $1 \mathrm{~L}$ of demineralized water. The $\mathrm{pH}$ was adjusted to 8.0 with $\mathrm{HCl}$ and salinity was set to $960 \mathrm{mOsm} / \mathrm{kg}$ before filter sterilization (pore size $0.22 \mu \mathrm{m}$ ).

Filtered seawater (FSW) was prepared by filter sterilizing (pore size $0.22 \mu \mathrm{m}$ ) fresh seawater collected from Lake Grevelingen. Salinity was $960 \mathrm{mOsm} / \mathrm{kg}$ and the $\mathrm{pH}$ was 8.0.

The propidium iodide staining solution $(3.8 \mathrm{mM}$ sodium citrate, $40 \mu \mathrm{g} / \mathrm{ml}$ PI (Sigma-Aldrich, Zwijndrecht, Netherlands; Cat.\#P4170) in phosphate-buffered saline (PBS)) was prepared by dissolving $98.1 \mathrm{mg}$ sodium citrate and $4 \mathrm{mg}$ of propidium iodide in $100 \mathrm{ml}$ of phosphate-buffered saline and was stored at $4{ }^{\circ} \mathrm{C}$ in the dark.

The RNase A stock solution $(10 \mu \mathrm{g} / \mathrm{ml})$ was prepared by dissolving $1 \mathrm{mg}$ of RNase A (Roche Diagnostics, Almere, Netherlands; Cat.\#10109142001) in $100 \mathrm{ml}$ demineralized water, and was boiled for $5 \mathrm{~min}$, aliquoted and stored at $-20^{\circ} \mathrm{C}$.

Wash buffer (PBS $+0.1 \%$ BSA) was prepared by dissolving $0.1 \mathrm{~g}$ of bovine serum albumin (BSA) in $100 \mathrm{ml}$ phosphate-buffered saline.

The passive lysis buffer (Promega, Fitchburg, WI; Cat.\# E1941) was prepared by diluting the buffer five times with demineralized water.

Sponge cell dissociation. The protocol used to prepare a sponge cell suspension was based on the method of Pomponi 
and Willoughby (1994). The sponge was rinsed in FSW and cut into small pieces of 1 to $2 \mathrm{~cm}$. The sponge parts were transferred to a Petri dish containing CMF-EDTA (10:1, CMF-EDTA volume/sponge volume). After soaking the sponge in CMF-EDTA and squeezing it through a sterile gauze, cells were easily released and the cell suspension was filtered using a $70-\mu \mathrm{m}$ cell strainer (BD Falcon ${ }^{\mathrm{TM}}$, BD Biosciences, Breda, Netherlands; Cat.\#352350) to remove cell aggregates and spicules. The crude cell suspension was centrifuged (Heraeus Primo centrifuge, Thermo Scientific, Breda, Netherlands) at $300 \times \mathrm{g}$ for $5 \mathrm{~min}$ to enrich for sponge cells, which were in the pellet, and remove most of the bacteria, which were in the supernatant. The supernatant was discarded and the cell pellet was resuspended in CMF-EDTA to be able to determine the cell concentration by counting with a disposable hemacytometer (C-Chip DHC-N01, Incyto, Orange Medical, Tilburg, Netherlands) using a microscope (Inverted fluorescence microscope IX-71, Olympus, Zoeterwoude, Netherlands).

Cultivation experiment with $H$. oculata. Two cultivation experiments were done with $H$. oculata, in December 2009 and January 2010. The sponge cells were dissociated as described in Section "Sponge cell dissociation". For each experiment, the cell concentration was set to $\sim 10^{6}$ cells $/ \mathrm{ml}$ in FSW. To resuspend the cells in FSW, a certain volume of cells in CMF-EDTA was centrifuged at $300 \times g$ for $5 \mathrm{~min}$ and the cells in the pellet were resuspended in a certain amount of FSW to acquire $\sim 10^{6}$ cells $/ \mathrm{ml}$. The cells were cultured in T25 flasks, $5 \mathrm{ml}$ per flask, and incubated at the same temperature of Lake Grevelingen, which was at that time $2^{\circ} \mathrm{C}$.

During the first experiment, one sponge was dissociated and the cells were incubated for $2 \mathrm{~d}$. At days 0 and 2, samples were taken for flow cytometry analysis (see Section "DNA staining and cell cycle analysis using flow cytometry") and for caspase measurements and total protein content (see Section "Caspase 3/7 measurements and total protein content"). Also, at day 1, part of the T25 flasks with sponge cells were exposed to $0.5 \mathrm{~h}$ of UV light to induce apoptosis. These cells were harvested at day 2. During the second experiment three sponges were dissociated, and the cells were incubated for $10 \mathrm{~d}$. Every day cells were harvested for all three analyses and cell counting. Again at day 1, part of the T25 flasks with sponge cells were exposed to $0.5 \mathrm{~h}$ of UV light and these flasks were harvested at day 2 .

DNAstainingandcellcycleanalysisusingflowcytometry. The cells were harvested and a single cell suspension was prepared by spinning down $5 \mathrm{ml}$ (T25 flask) of cells $(300 \times g, 5 \mathrm{~min})$ and resuspending the pellet in $1 \mathrm{ml}$ of CMF-EDTA. If aggregates were still present, the suspension was vortexed briefly. To $300 \mu \mathrm{l}$ of cell suspension, $900 \mu \mathrm{l}$ of ice-cold absolute ethanol was added drop-wise while vortexing.
Samples were stored at $-20^{\circ} \mathrm{C}$ for at least $1 \mathrm{~h}$ and could be stored at $-20^{\circ} \mathrm{C}$ for several weeks. After fixation, cells were washed twice at room temperature with $1 \mathrm{ml}$ of wash buffer (PBS $+0.1 \%$ BSA) by centrifuging at maximum speed $(13,000 \mathrm{rpm})$ for $1 \mathrm{~min}$ and resuspending the pellet in the wash buffer. Finally, the pellet was resuspended in $1 \mathrm{ml}$ of propidium iodide staining solution by pipetting up and down and briefly vortexing. Also $50 \mu \mathrm{l}$ of RNase A stock solution was added and the fixed cells were incubated for $3 \mathrm{~h}$ at $4{ }^{\circ} \mathrm{C}$ (Crissman and Steinkamp 1973; Krishan 1975). Fluorescence due to PI staining was measured in a flow cytometer (FACScalibur, Becton Dickinson, Franklin Lakes, NJ). The instrument settings for each sponge species are given in Table 2.

Caspase 3/7 measurements and total protein content. For the caspase measurements, $5 \mathrm{ml}$ (T25 flask) cells were harvested by spinning down the cells $(300 \times g, 5 \mathrm{~min})$ and removing the supernatant. Subsequently, $1 \mathrm{ml}$ of passive lysis buffer was added to the pellet, and the cells were dissolved by pipetting. The cells were incubated $20 \mathrm{~min}$ at room temperature to lyse all cells. The cell debris was spun down by centrifuging at maximum speed $(13,000 \mathrm{rpm})$ for $5 \mathrm{~min}$. The supernatant was aliquoted per $100 \mu \mathrm{l}$ and stored at $-20^{\circ} \mathrm{C}$ for further analysis. To measure caspase activities, we applied the caspase glo $^{\circledR} 3 / 7$ assay from Promega (Promega, Fitchburg, WI; Cat.\#G8090), which is a luminescent assay that can measure caspase 3 and 7 activities of cell suspensions. Measurements were performed in a luminometer (LUMIstar OPTIMA, BMG Labtech, Offen-

Table 2. Flow cytometer settings

\begin{tabular}{llll}
\hline & Voltage & Amplifier & Scale \\
\hline $\begin{array}{l}\text { Haliclona oculata and Haliclona } \\
\text { xena }\end{array}$ & & & \\
FSC & $\mathrm{E}+00$ & 5.00 & Linear \\
SSC & 450 & 1.00 & Linear \\
FL 2 & 750 & 1.00 & Linear \\
Dysidea avara & & & \\
FSC & $\mathrm{E}+00$ & 4.00 & Linear \\
SSC & 450 & 1.00 & Linear \\
FL 2 & 600 & 1.00 & Linear \\
Axinella polypoides & & & \\
FSC & $\mathrm{E}+00$ & 5.00 & Linear \\
SSC & 450 & 1.00 & Linear \\
FL 2 & 675 & 1.00 & Linear \\
Xestospongia muta & & & \\
FSC & $\mathrm{E}+00$ & 5.00 & Linear \\
SSC & 600 & 1.00 & Linear \\
FL 2 & 675 & 1.00 & Linear \\
\hline
\end{tabular}

FSC forward scatter, SSC side scatter, FL 2 fluorescence detector 2 
Figure 1. Left scatter plots of FSC-Height (cell size) versus FL2-Height (red fluorescence DNA content). Right singleparameter histograms of FL2Height (red fluorescence DNA content). $a, b$ : Haliclona oculata, collected at 16 November 2009; c, d: Haliclona xena;

$e, f$ : Dysidea avara;

$g, h$ : Axinella polypoides;

$i, j$ : Xestospongia muta.

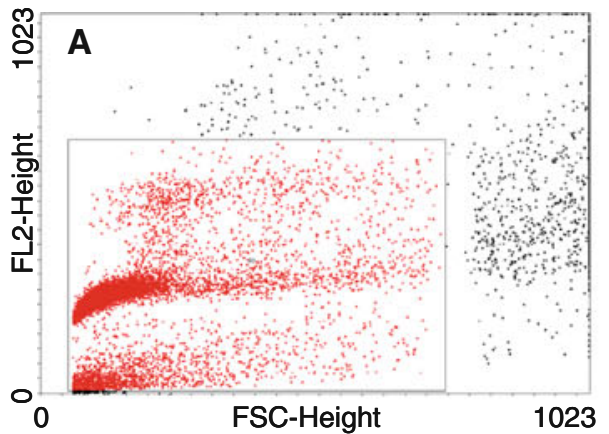

\section{$\stackrel{\infty}{\sim} \mathbf{B}$}
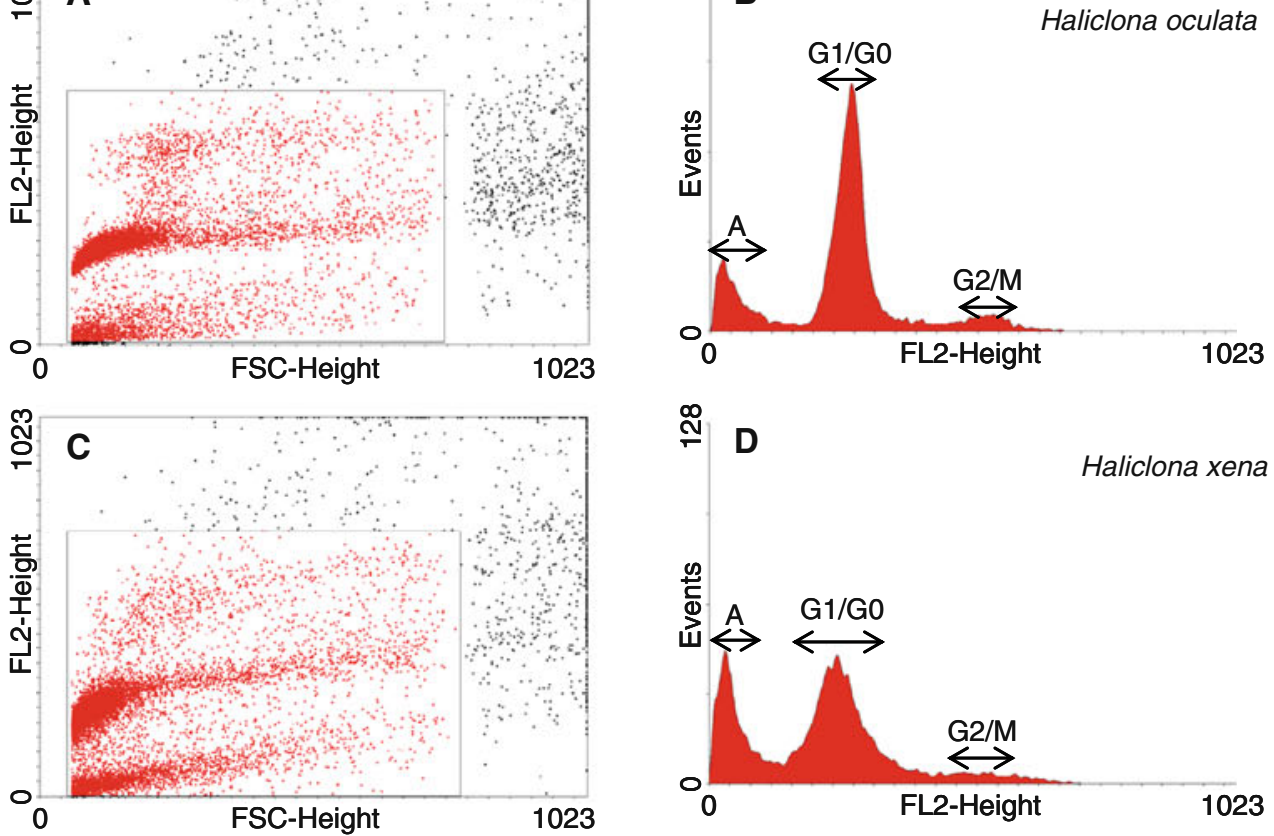

$\stackrel{\infty}{\text { N }} \mathbf{D}$

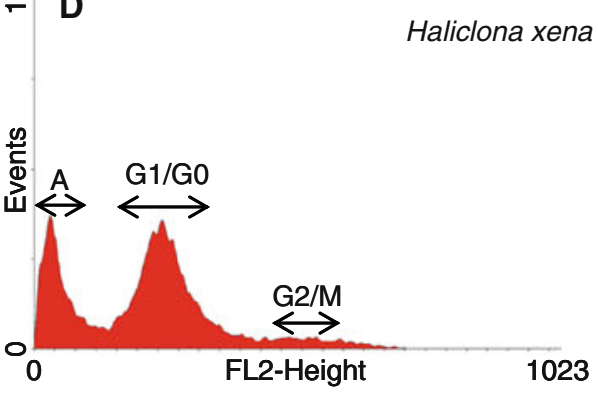

$\stackrel{\infty}{\underline{N}}$
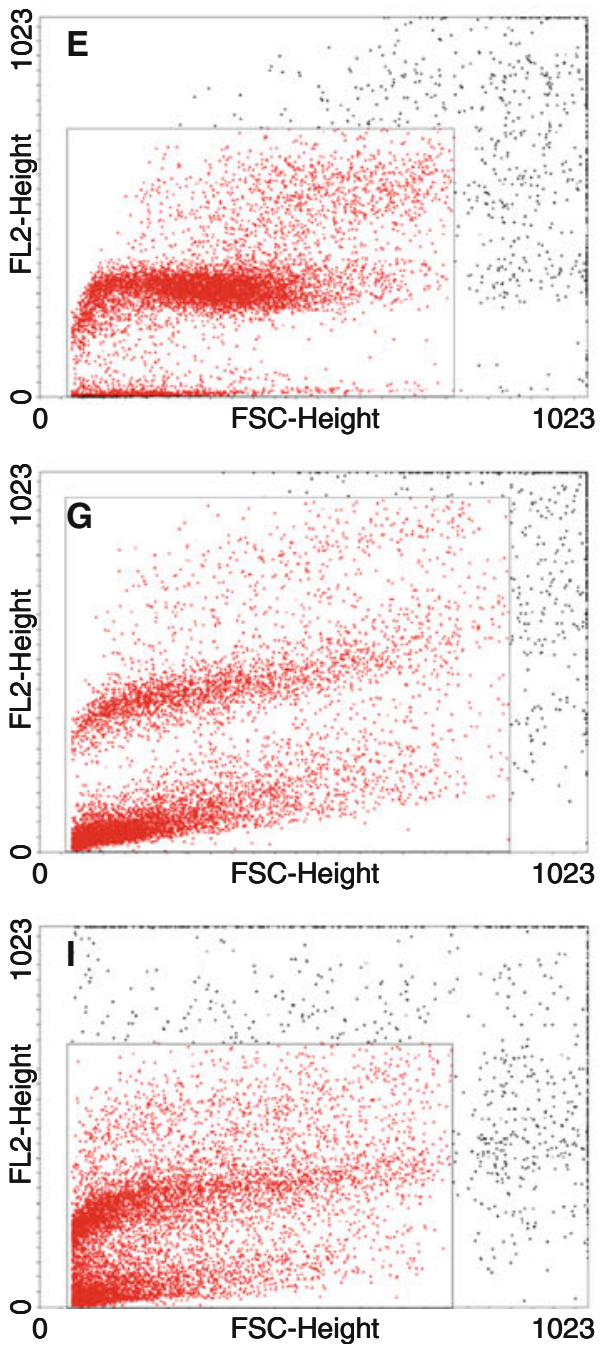

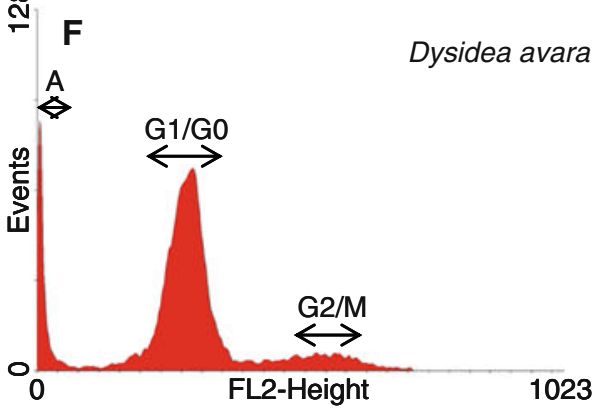

$\stackrel{\infty}{N}$

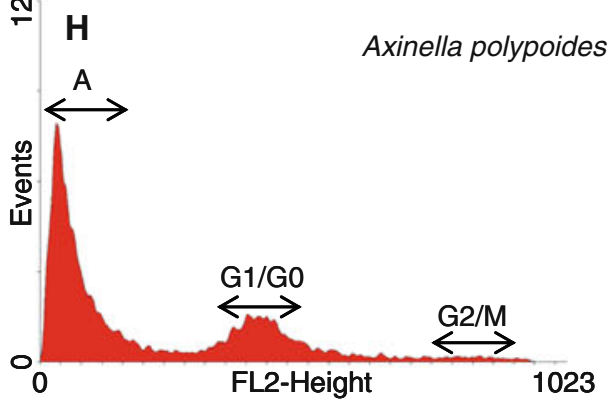

$\stackrel{\infty}{\sim}$

J

Xestospongia muta

$\stackrel{\infty}{\frac{\infty}{0}}$

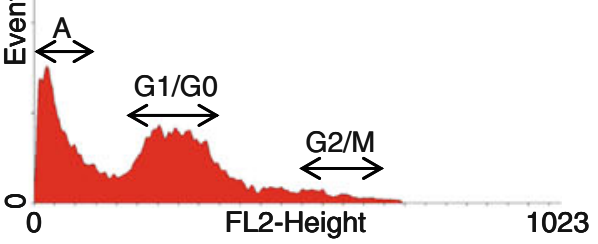


burg, Germany) using 96 white-walled well plates. To $25 \mu \mathrm{l}$ of stored supernatant, $25 \mu \mathrm{l}$ of caspase glo reagent was added and incubated for minimally $30 \mathrm{~min}$ and maximally $3 \mathrm{~h}$ at room temperature. The blank was made of $25 \mu$ passive lysis buffer and $25 \mu \mathrm{l}$ caspase glo reagent. SF21 insect cells incubated with Actinomycin D were used as a positive control and SF21 cells were included as a negative control.

To measure total protein content of the lysed cells, we applied the Bio-Rad Protein Assay Kit II (Bio-Rad Laboratories, Veenendaal, Netherlands; Cat.\#500-0002), which is based on the method of Bradford. Measurements were performed in a spectrophotometer (LUMIstar OPTIMA, BMG Labtech, Offenburg, Germany) set to $595 \mathrm{~nm}$, using 96-well transparent ELISA plates. BSA $(0.5,0.25$, 0.125 , and $0.065 \mathrm{mg} / \mathrm{ml}$ ) was used as the protein standard. To $10 \mu \mathrm{l}$ of stored supernatant, $200 \mu \mathrm{l}$ of $1 \times$ Dye Reagent was added and incubated for $\sim 10 \mathrm{~min}$ at room temperature. Since the linear range of the microtiter plate assay is only $0.05 \mathrm{mg} / \mathrm{ml}$ to approximately $0.5 \mathrm{mg} / \mathrm{ml}$, we also measured a $10 \times$ dilution of each sample.

During the first cultivation experiment, measurements were performed in duplicate, for the second cultivation experiment all measurements were performed in triplicate.

\section{Results}

Cell cycle analysis of five different species. Cell cycle distribution was measured for five different sponge species, obtained from different locations. Figure 1 represents the cell cycle distribution of these five sponges. The figures on the left show scatter plots of forward scatter (FSC-Height), which is a relative measure for cell size, versus red fluorescence (FL2-Height), which is a relative measure for DNA content. The figures on the right show singleparameter histograms of red fluorescence (DNA content). For all five species the cell populations have a broad range of FSC values, which means that cells with the same DNA content cover a wide range of cell sizes. This is as expected, because sponges contain many different cell types with different sizes $(\sim 10 \mu \mathrm{m}$ choanocytes compared to $\sim 50 \mu \mathrm{m}$ archaeocytes) and we did not select for a certain cell type. All scatter plots show three populations of cells: the middle population represents cells residing in $\mathrm{G} 1 / \mathrm{G} 0$ phase, the upper population, located at a red fluorescence of 1.8-2.0 times that of G1/G0 population, represents cells in the G2/M phase, and the lower population represents apoptotic cells. The S phase cells are located between the G1/G0 and G2/M populations and are hardly or not present here. A single gate
Figure 2. First cultivation experiment with $H$. oculata, collected at 16 November 2009. Left scatter plots of FSC-Height (cell size) versus FL2-Height (red fluorescence DNA content). Right single-parameter histograms of FL2-Height (red fluorescence DNA content).
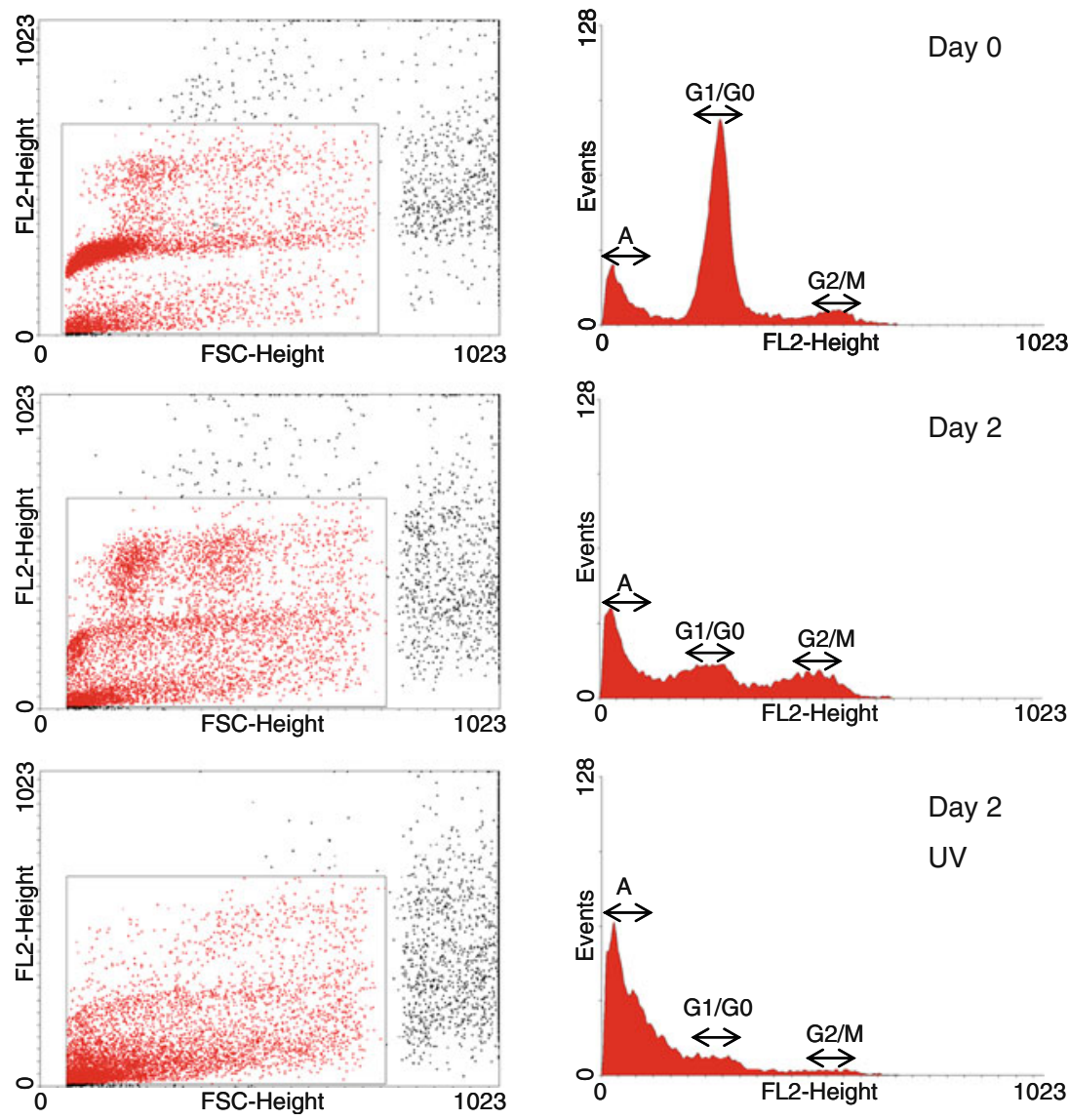
was placed around these three populations of cells as shown by the squares in Fig. 1 and cells inside the gate were plotted in the single-parameter histograms of red fluorescence (DNA content). This provided data for estimations of distribution of cells existing in G0/G1 (2N DNA), in S (2-4N DNA), in G2/M (4N DNA), and in the apoptotic population $(<2 \mathrm{~N}$ DNA).

Cultivation experiments $H$. oculata: Cell cycle analysis with flow cytometry. Figure 2 shows the scatter plots and single-parameter histograms of $H$. oculata from the first cultivation experiment. The first cultivation lasted for $2 \mathrm{~d}$, and cells were harvested at day 0 (right after dissociation) and at day 2. To confirm that apoptosis is indeed occurring and that the population with the low red fluorescence consists of apoptotic cells or their remnants, a control sample was exposed on day 1 to $0.5 \mathrm{~h}$ of UV light, which is a known in ducer of apoptosis and analyzed on day 2 (day 2 UV).

For the second experiment some adjustments were made compared to the first experiment. Cells from three different sponges, instead of one sponge, were used, and cells were cultivated for $10 \mathrm{~d}$ instead of $2 \mathrm{~d}$. In addition to cell cycle analysis, cell concentrations were determined during the second experiment. Figure 3 shows the scatter plots and single-parameter histograms of $H$. oculata of the second cultivation experiment. Only the results of one sponge are shown, since the other two sponges gave similar results. Figure 3 also does not show results of day 3 till day 9, since the results did not change much between days 2 and 10 .
Figure 3. Second cultivation experiment with $H$. oculata, collected at 11 January 2010. Left scatter plots of FSC-Height (cell size) versus FL2-Height (red fluorescence DNA content). Right single-parameter histograms of FL2-Height (red fluorescence DNA content).
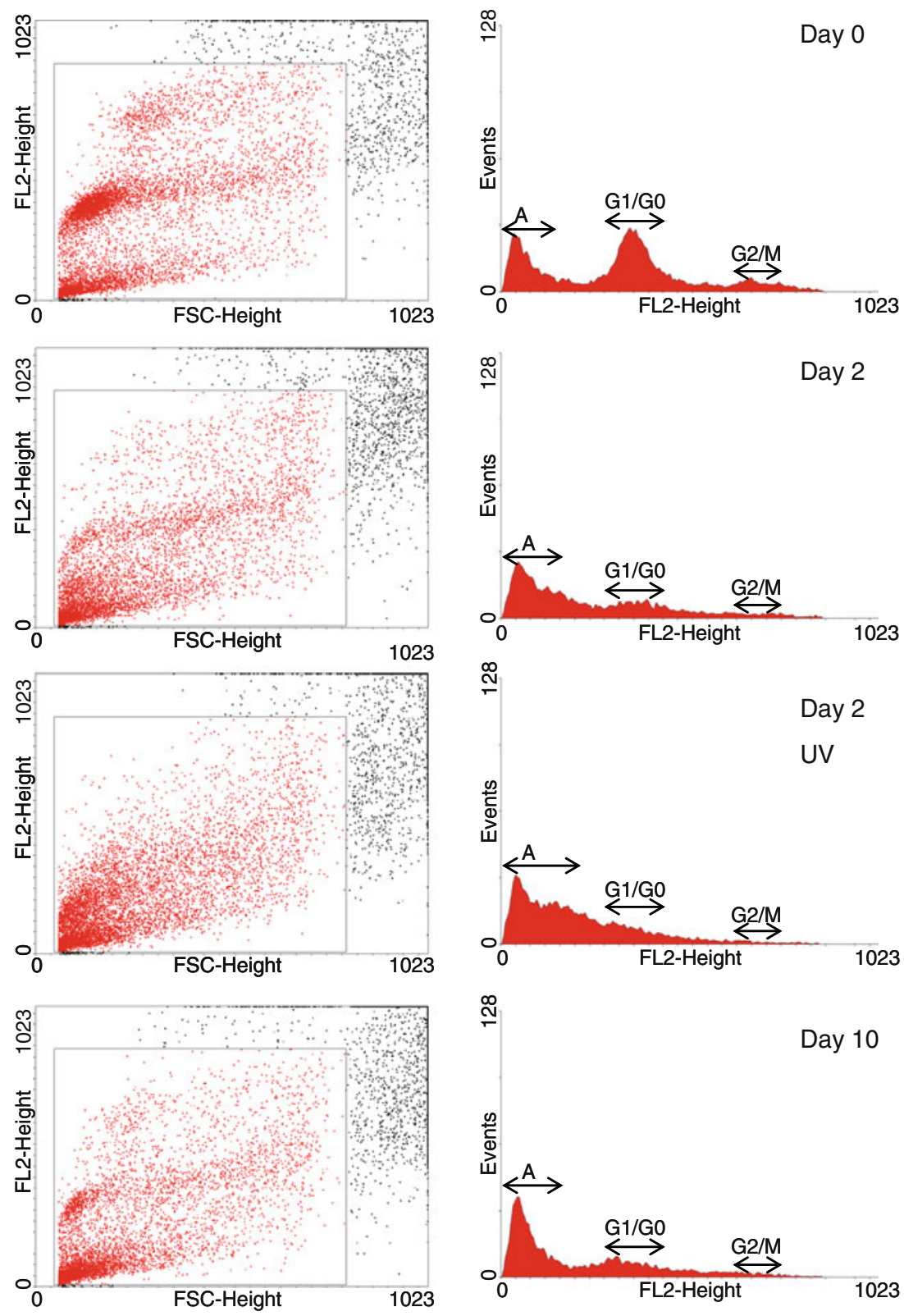
Figure 4 shows the cell concentrations (with standard deviation) of the second cultivation experiment of all three sponges. The cell concentration at the start of the experiment was 1.1 million cells per milliliter and after 10 days of cultivation the cell concentration was 0.7 million cells per milliliter, which indicates that approximately one third of the cells died and lysed after $10 \mathrm{~d}$ of cultivation.

Cultivation experiments $H$. oculata: Caspase activity per total protein content. To confirm that the lowest population of cells in the scatter plots were really apoptotic cells, an additional assay, based on measurements of caspase 3/7 activity, was used. To be able to compare the results of each sample, we divided the caspase activities by the total amount of protein, assuming that there is a relation between total protein content and cell numbers. Since cells do not have to be monodisperse for this method, we could also use a sample of fresh, not dissociated sponge material, which made it possible to observe the effect of the dissociation process on apoptosis. For the cell cycle analysis method this is not possible, because sponge tissue has to be dissociated before it can be fixed and stained with PI. The positive control consisted of insect cells (SF21 ActD) incubated with actinomycin D, which inhibits transcription and interferes with DNA replication, causing cells to go into apoptosis (Clem and Miller 1994). The negative control consisted of continuously dividing insect cells (SF21 ActD), which are expected to show no apoptosis. To be able to compare measurements of both experiments, which were measured at different gains, all results were normalized in relation to SF21 ActD, since this sample was the same in both experiments. Figure 5 shows the results of the caspase activity per total amount of protein. The results for the negative and the positive control are as expected. Exponentially growing SF21 cells show a negligible caspase activity in comparison to SF21 cells treated with ActD.

\section{Discussion}

Cell cycle distribution. For five different sponge species the cell cycle distribution was measured (Fig. 1) and all scatter plots show three populations of cells. The middle population represents cells in the $\mathrm{G} 1 / \mathrm{G} 0$ phase. The upper population, located at a red fluorescence 1.8-2.0 times that of the G1/G0 population, represents cells in the $\mathrm{G} 2 / \mathrm{M}$ phase. This ratio of $1.8-2.0$ is in general found for different types of cells and confirms that these populations are indeed $\mathrm{G} 1 / \mathrm{G} 0$ and $\mathrm{G} 2 / \mathrm{M}$. For example, the ratio between the middle population $(\mathrm{G} 1 / \mathrm{G} 0)$ and the lowest population is much higher. The cells between the middle and upper population are considered to reside in the $\mathrm{S}$ phase. The lowest population of cells is most likely the apoptotic population, which represents cells with fragmented DNA, but can also contain some cell debris, like apoptotic bodies and possibly some bacterial contamination. However, the bacterial contamination is negligible, since most of the bacteria were removed from the cell suspension by differential centrifugation. Thus, most likely this population represents cells with fragmented DNA and can therefore be considered to be the apoptotic population.

To confirm that the lowest population consists of apoptotic cells, for both cultivation experiments a sample was exposed to UV light, which is a known inducer of apoptosis. Figures 2 and 3 illustrate that $1 \mathrm{~d}$ after UV exposure, almost all cells are in the lowest population, indicating that indeed this population contains apoptotic cells.

In addition to flow cytometric cell cycle analysis, caspase activity of the cells was measured for both cultivation experiments. Caspase activity is an indicator of early apoptosis. When comparing the results of day 2 with results of day 2 after UV exposure (Fig. 5), for both experiments, an increase in caspase was observed, indicat-
Figure 4. Cell density during time of second cultivation experiment with $H$. oculata, collected at 11 January 2010 , with standard deviation.

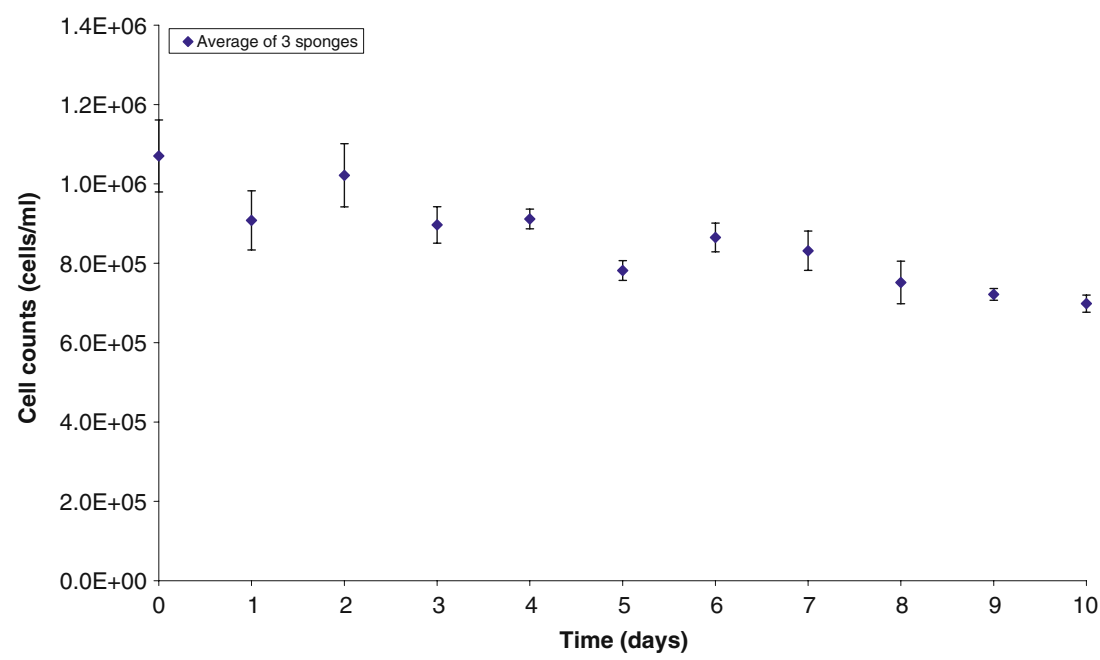


Figure 5. Caspase activity per total protein, normalized in relation to the positive control, insect cells incubated with actinomycin D (SF21 ActD), with standard deviation.

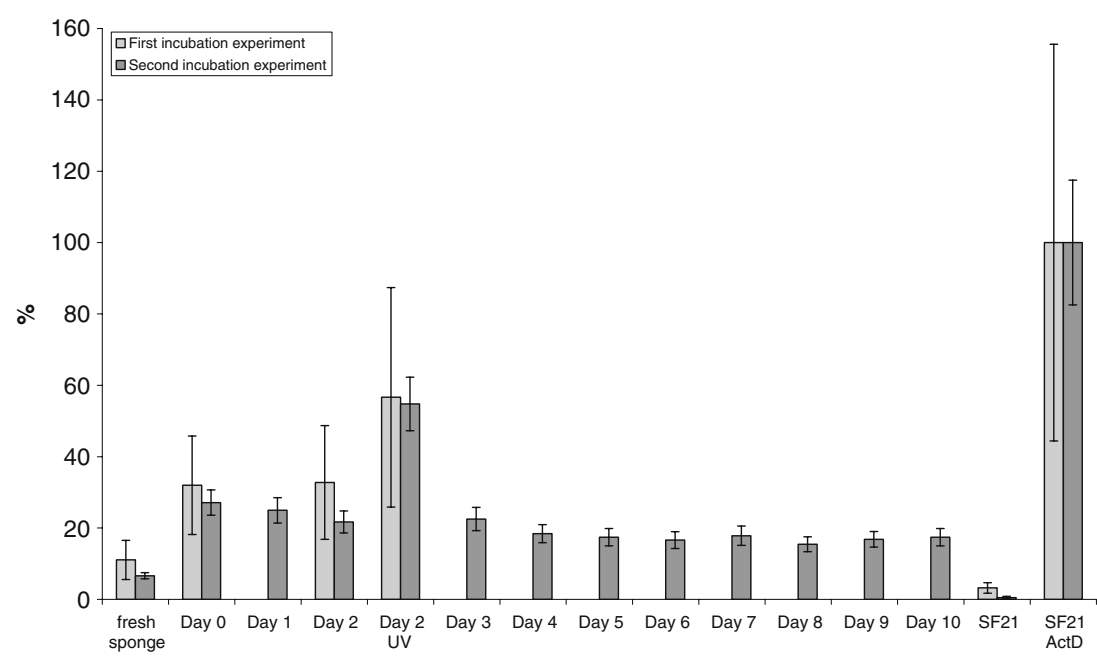

ing that indeed UV light induces apoptosis. This increase in caspase activity correlates with the increase in the size of the lowest population as observed by flow cytometry, confirming that the lowest population is indeed an apoptotic population.

Different species. The scatter plots of all five sponges in Fig. 1 show three populations of cells, although for $H$. oculata, $H$. xena, and $D$. avara these three populations can be seen more clearly than for $A$. polypoides and $X$. muta. For all five sponges the G1/G0 fraction is much larger than the G2/M fraction and the S-phase fraction is hardly visible. This indicates that most of the cells were not actively dividing or were dividing very slowly. There is also an apoptotic population which is largest for $A$. polypoides and lowest for $D$. avara. The size of this apoptotic population may represent the viability of the sponge. At the time of harvest, D. avara looked very healthy and was present abundantly, which may explain the low apoptotic fraction and the clear cell cycle distribution. On the other hand, apoptosis may also be due to harvesting and treatment of the sponges which in this case would indicate that D. avara is less sensitive to this treatment than the other four sponges.

Cultivation experiments $H$. oculata. Two cultivation experiments were executed with $H$. oculata. During both experiments, the cell cycle distribution (Figs. 2 and 3) and the caspase activity (Fig. 5) were measured and for the second experiment also the cell density (Fig. 4) was determined. Figure 5 shows that there is approximately a threefold increase of caspase activity for both experiments between the fresh sponge sample and the day 0 sample after harvesting and dissociation, which indicates that harvesting, transporting, and dissociating the sponge induced apoptosis. By dissociating the sponge, cells are removed from their extracellular matrix and will lose cell-cell contact and adhesion. It is known for primary cells that these factors are important for survival (Freshney 2005). Also filtering, centrifuging, and resuspending the cells will cause shear stress, which is another potential cause of cell death (Laken and Leonard 2001). To circumvent these apoptosis inducing factors, tissue or explant culture, for which dissociation into cells is not required, could be a solution (Camacho et al. 2006).

When comparing the cell cycle distributions at day 0 of both experiments, we can see that for the first cultivation experiment (Fig. 2), most cells were in the G1/G0 phase and the apoptotic population was relatively small in comparison with the G1/G0 population. For the second cultivation experiment (Fig. 3) most cells were also in the G0/G1 phase, but there is also a large apoptotic fraction, which is clearly larger than the apoptotic fraction in the first experiment. In other words, the cell population at the start of the second experiment was less viable as compared to the first experiment. This suggests that the selected sponges for the second experiment were either less viable or more sensitive to the dissociation process. However, there is no significant difference in caspase activity between the first and second cultivation experiment (Fig. 5).

When comparing the cell cycle distributions at days 0 and 2 for both cultivation experiments, a decline in the fraction of cells in $\mathrm{G} 1 / \mathrm{G} 0$ and an increase in the apoptotic fraction can be observed (Figs. 2 and 3), implying that most cells died or were dying. However, when observing the cell counts in Fig. 4, we can see that there was no significant decrease of cell numbers between days 0 and 2 . This shows the added value of measuring the different subpopulations, showing that although there was no decrease in cell number, the majority of the cells were, in fact, dying. Still, at day 2 of the first experiment, a small increase of the G2/M fraction can be observed. A possible explanation is that the absolute number of cells in $\mathrm{G} 2 / \mathrm{M}$ remained constant, while the total number 
decreased, which automatically means that the fraction of G2/M increases. However, it is also possible that part of the G1 cells were actively dividing and moved to the $\mathrm{G} 2 / \mathrm{M}$ population.

Between days 3 and 10 of the second experiment, the caspase activities do not increase anymore (Fig. 5). This could be explained by the fact that the sponges were harvested during winter and that water temperatures were $2{ }^{\circ} \mathrm{C}$. Therefore, also the cultivation temperature was set to $2^{\circ} \mathrm{C}$ and at this temperature all biological processes slow down including apoptosis (Koopmans and Wijffels 2008). Another explanation could be that the rate of cells going from the $\mathrm{G} 1 / \mathrm{G} 0$ fraction towards the apoptotic fraction, is just as large as the rate of apoptotic cells lysing, keeping the fraction of apoptotic cells constant.

The cell cycle distribution at day 10 (Fig. 3) shows that most cells were in the apoptotic phase. However, we can also still see a clear population of cells in the G1/G0 phase, and a very small population in the G2/M phase, which means that not all cells have become apoptotic. This could imply that from the cell population at the start, only a small subpopulation of cells is proliferating, while the majority of cells is dying. If this is the case, it may be necessary to culture for longer periods of time in order to get rid of the non-proliferative cells, because they will die and fall apart and thus select for the few cells that are able to proliferate.

\section{Conclusions}

Flow cytometric cell cycle analysis allows for a quick determination of the proliferative status of a cell population for sponge cells. This method makes it possible to distinguish between apoptotic, G1/G0, S, and G2/M phase cells. Apoptosis was confirmed using a caspase assay. Sponge cells obtained from different sponges all showed a large fraction of cells in G1/G0 compared to G2/M and S, which was hardly present. Some sponges also showed a large apoptotic fraction. This indicates that cells were not actively dividing. Apoptosis measurements using an enzymatic caspase assay show that the large apoptotic fraction is at least in part due to harvesting and dissociation of the sponge. Cultivation of the sponge cells resulted in a further increase in the apoptotic cell fraction indicating that either the cultivation conditions do not support proliferation or that the collected sponges itself may be in a nonproliferative state. In future, this flow cytometric cell cycle analysis method in combination with caspase measurements can be used to validate improvements in harvesting and dissociation and to study the influence of culture conditions on cell proliferation, in order to develop an in vitro sponge cell culture.
Acknowledgments This research was supported by IPOP Coast and Sea, Graduate School VLAG and the Florida Sea Grant (R/LR-MB-25). We thank M. Koopmans for collecting D. avara and R. Baumberger for collecting $X$. muta. Also, we would like to thank G. Pijlman, C. Geertsema, and S. Metz from the Laboratory of Virology at Wageningen University for their help with the caspase and Bradford protein assays and providing the SF21 cells.

Open Access This article is distributed under the terms of the Creative Commons Attribution Noncommercial License which permits any noncommercial use, distribution, and reproduction in any medium, provided the original author(s) and source are credited.

\section{References}

Camacho, F. G.; Chileh, T.; García, M. C. C.; Mirón, A. S.; Belarbi, E. H.; Gómez, A. C.; Grima, E. M. Sustained Growth of Explants from Mediterranean Sponge Crambe crambe Cultured In Vitro with Enriched RPMI 1640. Biotechnology Progress. 22: 781-790; 2006.

Clem, R. J.; Miller, L. K. Control of programmed cell death by the baculovirus genes p35 and iap. Molecular and Cellular Biology. 14: 5212-5222; 1994.

Crissman, H. A.; Steinkamp, J. A.. Rapid, simultaneous measurement of DNA, protein, and cell volume in single cells from large mammalian cell populations. The Journal of Cell Biology. 59: 766-771; 1973.

De Caralt, S.; Uriz, M. J.; Wijffels, R. H. Cell culture from sponges: pluripotency and immortality. Trends in biotechnology. 25: 467$471 ; 2008$.

Fertig, G.; Klöppinger, M.; Miltenburger, H. G. Cell cycle kinetics of insect cell cultures compared to mammalian cell cultures. Experimental Cell Research. 189: 208-212; 1990.

Freshney, R. I. Culture of animal cells: a manual of basic technique. Wiley-Liss, Hoboken; 2005.

Koopmans, M.; Martens, D.; Wijffels, R. H. Towards Commercial Production of Sponge Medicines. Marine Drugs. 7: 787-802; 2009.

Koopmans, M.; Wijffels, R. H. Seasonal growth rate of the sponge Haliclona oculata (demospongiae: Haplosclerida). Marine Biotechnology. 10: 502-510; 2008.

Krishan, A. Rapid flow cytofluorometric analysis of mammalian cell cycle by propidium iodide staining. The Journal of Cell Biology, 66: 188-193; 1975.

Laken, H. A.; Leonard, M. W. Understanding and modulating apoptosis in industrial cell culture. Current Opinion in Biotechnology. 12: 175-179; 2001.

Munro, M. H. G.; Blunt, J. W.; Dumdei, E. J.; Hickford, S. J. H.; Lill, R. E.; Li, S.; Battershill, C. N.; Duckworth, A. R. The discovery and development of marine compounds with pharmaceutical potential. Journal of Biotechnology. 70: 15-25; 1999.

Nicholson, D. W.; Thornberry, N. A. Caspases: killer proteases. Trends in Biochemical Sciences. 22: 299-306; 1997.

Pomponi, S. A. The bioprocess-technological potential of the sea. Journal of Biotechnology. 70: 5-13; 1999.

Pomponi, S. A. Biology of the Porifera: Cell culture. Canadian Journal of Zoology. 84: 167-174; 2006.

Pomponi, S. A.; Willoughby, R. Sponge cell culture for the production of bioactive metabolites. In: Van Soest, R.; Van Kempen, T. M. G.; Braekman, J. C. (eds.) Sponges in time and space. Balkema, Rotterdam, 1994.

Pomponi, S. A.; Willoughby, R.; Kaighn, M. E.; Wright, A. E. Development of techniques for in vitro production of bioactive natural products from marine sponges. In: Maramorosch, K.; Mitsuhashi, J. (eds.) Science Publishers, USA 1997. 
Pozarowski, P.; Darzynkiewicz, Z. Analysis of cell cycle by flow cytometry. Methods in Molecular Biology. 281: 301-11; 2004.

Rinkevich, B. Marine invertebrate cell cultures: new millennium trends. Marine Biotechnology, 7: 429-439; 2005.

Sipkema, D.; Franssen, M. C. R.; Osinga, R.; Tramper, J.; Wijffels, R. H. Marine sponges as pharmacy. Marine Biotechnology. 7: 142-162; 2005a.

Sipkema, D.; Osinga, R.; Schatton, W.; Mendola, D.; Tramper, J.; Wijffels, R. H. Large-scale production of pharmaceuticals by marine sponges: Sea, cell, or synthesis? Biotechnology and Bioengineering. 90: 201-222; 2005b.

Sipkema, D.; Snijders, A. P. L.; Schroen, C. G. P. H.; Osinga, R.; Wijffels, R. H. The life and death of sponge cells. Biotechnology and Bioengineering. 85: 239-247; 2004.

Wiens, M.; Muller, W. E. G. Cell death in Porifera: molecular players in the game of apoptotic cell death in living fossils. Canadian Journal of Zoology-Revue Canadienne de Zoologie. 84: $307-$ $321 ; 2006$ 